\title{
DEVELOPMENT OF OCCUPATIONAL HEALTH IN LATVIA
}

Occupational health is a multidisciplinary science that concentrates on various aspects of workers safety and health at work. The $12^{\text {th }}$ session of the joint International Labor Organization (ILO) / World Health Organization (WHO) Committee in 1995 has made a statement that the focus in occupational health is on three objectives:

1) maintenance and promotion of workers health and working capacity;

2) improvement of working environment and work to become conducive to safety and health;

3) development of work organization and working culture which support health and safety at work, promotes a positive social climate and individual working ability and enhance productivity of the undertaking.

The WHO health policies has always included elements of occupational health. Health and safety at work are important for general well being and the health of working people that should be given due consideration in policies of all levels (i.e. company, national and international). Health and safety problems at work are preventable and should be prevented using all available tools - legislation, research, training and education, information, technical and economical measures. Governments are encouraged to implement national policies and programs for occupational health that include measures intended to achieve full coverage of all workers with occupational health services at work [16].

The occupational health team may include occupational physicians, occupational health nurses, occupational psychologists, physiotherapists, ergonomists, occupational hygienists, safety engineers, toxicologists, microbiologists, chemists, information technicians and others.

In this article we will provide short historical overview of development of occupational health in Latvia with main emphasis on most important discipline of occupational health - occupational medicine. 
Occupational medicine is a medical science that concentrates on:

- appraisal, maintenance, restoration and improvement of the workers health through application of the principles of clinical and preventive medicine, rehabilitation and environmental medicine;

- promotion of productive and healthy working environment via application of principles of human behaviour;

- team approach to health and safety, involving co-operation of the physician with the rest of specialists working for occupational health team [2].

Occupational diseases existed ever since people learned how to use tools in order to improve their living conditions. Occupational medicine as science started to develop many centuries ago. Already Hippocrates (460-370 BC) knew about harmful working factors, occupational diseases and intoxication's caused by working conditions. Occupational medicine became more popular in medieval times when first factories with hard manual labour were established. First publications on occupational diseases are published by authors like Agricola, Paracelsus, Martin Pansa etc. First occupational health services were established for workers in many European countries during the $16^{\text {th }}$ and $17^{\text {th }}$ centuries $[1,5]$.

In 1713 a book "Thoughts about workers' diseases" by professor of Padua University (Italy) Bernardino Ramazzini (1633-1714) was published. This was the first time when occupational pathology for 60 professions was described in details. In 1910 first specialized clinic for occupational diseases were established in Milan the native town of Bernardino Ramazzini.

Since then occupational health has developed along the development of industry. Many occupational medicine clinics, research institutes and a department of occupational health at universities has been established in 20 the century.

Department of Hygiene at University of Latvia was established in 1921 and it was lead by Ernsts Fẽrmanis (1872-1947). After the Second World War Department of Hygiene was re-established in 1945 in leadership of Prof. Jānis Maizite (1883-1950). Riga Medical Institute was established in 1951 with Michail Garbarenko (1899-1962) as a head of Department of Hygiene; Prof. Zinaīda Lindberga (1916) was the head of this department from 1962 until 1990.

Scientific development of occupational health started in 28 of March 1966 when special department of hygiene and occupational diseases was established in Central Laboratory for Research and Science (CLRS) of Riga Medical institute. This department was founded by professor Levs Izrailietis (1924-1980) - key person for development of occupational health in Latvia.

Levs Izrailietis was born on $10^{\text {th }}$ of April 1924 in Karsava, small town in Latgale. At the beginning of Second World War he emigrated to Uzbekistan. During 1942-1949 he was a student at Moscow Medical Institute. Afterwards he began his career as a doctor in a small town nearby Moscow organizing medical examinations 


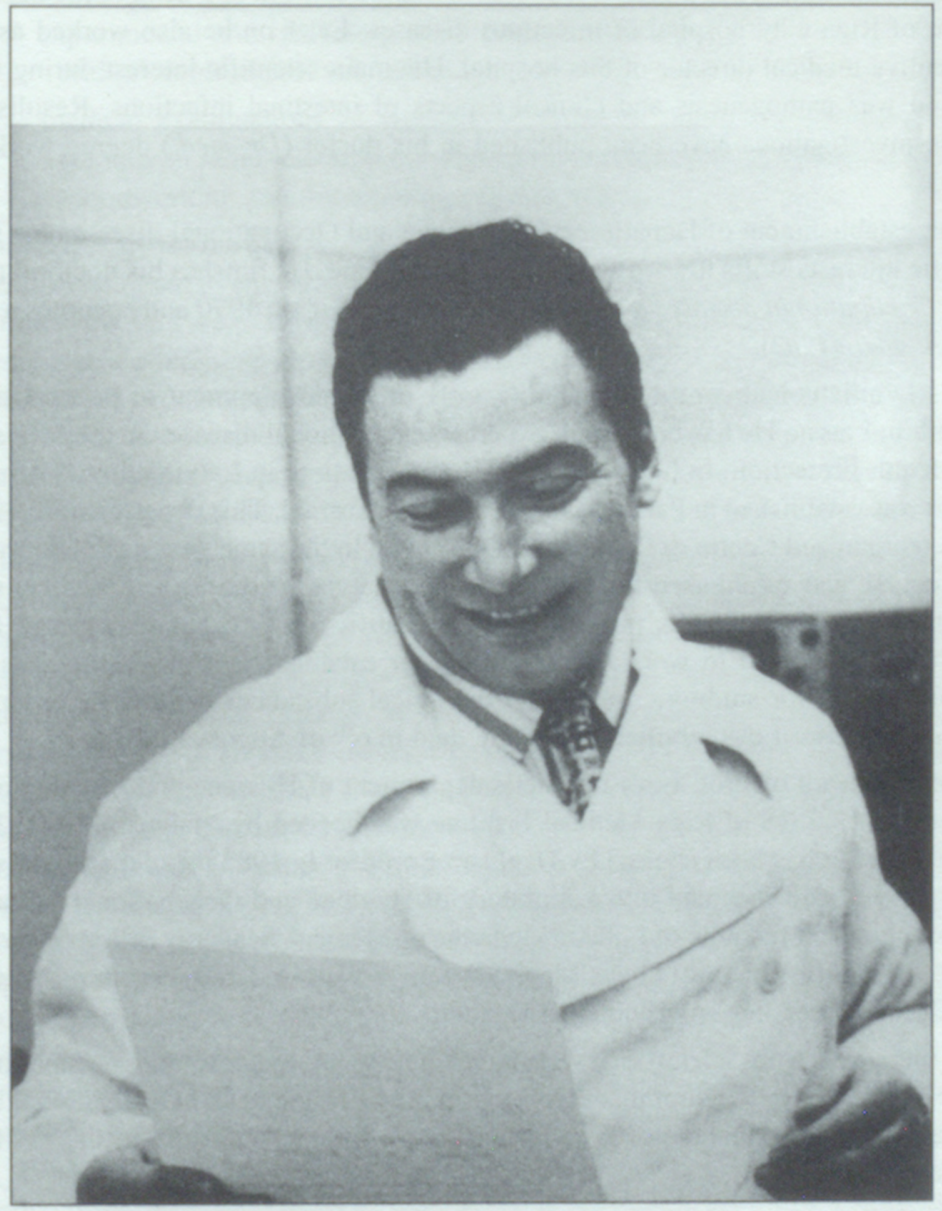

Professor Levs Izrailietis (1924-1980),

founder of the discipline of occupational medicine in Latvia. 1977 
for the workers of coal mines. From 1951 until 1957 he was at military service at Soviet Army. After demobilization in 1957 he entered clinical residency at Riga Medical Institute for two years. After that he started to work as a head of the department of Riga City hospital of infectious diseases. Later on he also worked as an executive medical director of this hospital. His main scientific interest during this period was pathogenesis and clinical aspects of intestinal infections. Results of these investigations have been published in his doctor $(D r$. med.) degree work at 1963.

After establishment of Department of Hygiene and Occupational diseases his scientific interests shifts towards occupational medicine. He finishes his doctoral thesis "Occupational diseases in production of antibiotics" in 1970 and becomes a Dr. habil. med. $(P h D)$.

Levs Izrailietis had contributed significantly to the development of occupational health in Latvia. He has been main expert of occupational diseases in the Ministry of Health Protection. In his leadership for the first time in Latvia clinical department was established in Pauls Stradin's Clinical Hospital. This department in 1977 was reorganized Centre of Occupational diseases. In the same year a clinical training course was established for the first time in Latvia for training of medical students. Levs Izrailietis has published 150 scientific articles. His experience and knowledge allowed to work out principles for establishment of Treshold Limit Values (TLV) for antibiotics and other biological substances in working environment. Professor Levs Izrailietis suddenly died in $6^{\text {th }}$ of August 1980.

After the death of Prof. Levs Izrailietis department of Hygiene and Occupational diseases of CLRS of Riga Medical Institute was headed by Maija Eglīte (1939). From 1990 it has been chaired by Dagmara Sprūdža. In 1982 this department was reorganized and renamed into Laboratory of Hygiene and Occupational diseases and included in Institute of Labour Medicine of Medical Academy of Latvia. After that in 1996 Institute of Labour Medicine was reorganized and turned to Institute of Occupational and Environmental Health.

As there were no scientific research institution for hygiene and occupational diseases one have to admit that this Department of Hygiene and Occupational diseases, later called Laboratory, was acting as an research institute in the field of occupational health.

Main direction of work in department of Hygiene and Occupational diseases in the period from 1966 to 1975 has been oriented towards problems of hygiene and occupational diseases in chemical - pharmaceutical industry. Work on establishment of TLV for various biological substances has been another laborious task. At the end of this period Levs Izrailietis published his doctoral thesis leading to Dr. habil. med. degree. V. Moskova, J. Aleksejevs, M. Baumane and Z. Simhovics finished their thesis for degree of dr. med. $[1,3,9]$ during this period.

Next ten years during 1976-1985 work was organized in three man directions: 
- research of hygienic conditions in working environment and work on improvements in work environment in order to reduce numbers of morbidity with occupational diseases;

- experimental and laboratory work with animals testing different chemicals and microbiological substances;

- medical examinations of workers in different industries and agriculture (mainly in radio -electronic, building material, chemical - pharmaceutical, woodworking and microbiological industries).

A new strategy for the department was set - from research to prevention. Particular attention was paid to encourage collaboration between scientists of different fields - clinical doctors were working together in research with environmental chemists, specialists of allergology, industrial toxicology and etc. Dr. med. thesis of M. Bake (1985) on environmental chemistry was first kind of this work showing how productive this co-operation can be $[7,10,12,13]$. Lots of scientific articles, books and methodological recommendations were published during this period including also two thesis of Dr. Med. for I. Kvjatkovskaja (1982) and I. Ivanova (1985).

In 1986 accident at Chernobyl Nuclear power plant (NPP) brought a new problem to Latvian specialists as more than 6000 Latvian inhabitants took part in accident clean-up works. Ministry of Health Protection of Soviet Union issued a number of regulatory documents regarding organization of regular medical examinations and registries for exposed persons in former Soviet republics. According to this Latvian Ministry of Health Protection issued an order (9.07.1987) to start medical examinations. Pauls Stradin's Clinical Hospital was ordered to be in charge for this task. Due to large number of clean-up workers and to fact that number of occupational patients also continued to grow Centre for Occupational Diseases were reorganized and enlarged in 1990. Functions of the head of the new centre were given to Maija Eglite (already in charge of the centre since 1980). New department of outpatients was established in result of this reorganization and was headed by Elvīra Čurbakova. In 1993 Centre was renamed to Centre of Occupational and Radiological Medicine. In 1994 State Registry for occupational patients and persons exposed to ionizing radiation after Chernobyl accident was established. Important role in the development of the Centre has been to clinical department Nr. 29 of Pauls Stradin's Clinical Hospital. It was established as department of internal diseases in 1953 with 45 beds. In 1969 extra beds were added for occupational patients. Department has also been involved in medical treatment of persons disabled after second world war but since 1990 it also serves Chernobyl NPP accident clean-up workers. First head of this department was Prof. Zeliks Čerfass. From 1962 until 1993 head of the department was Lija Dešalite - excellent specialist of internal medicine who later specialized in occupational medicine. One year (1989-1990) Tatjana Gauhmane headed the department. From 1993 to 1996 department was lead by Prof. Grigorijs Or|ikovs but since 1996 the head of the 


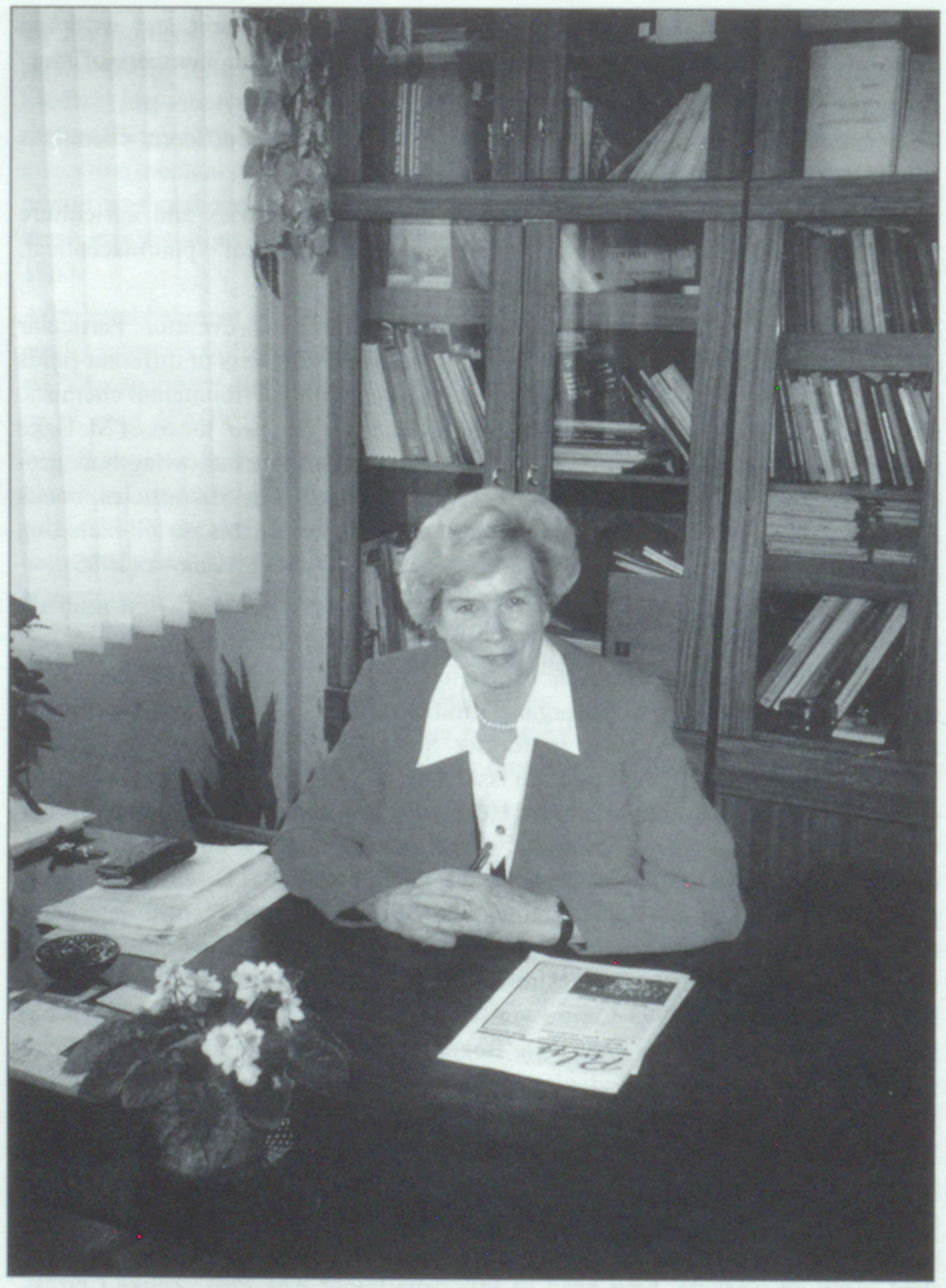

Professor Maija Eglīte,

current director of the Institute of Occupational and Environmental Health. 1997 


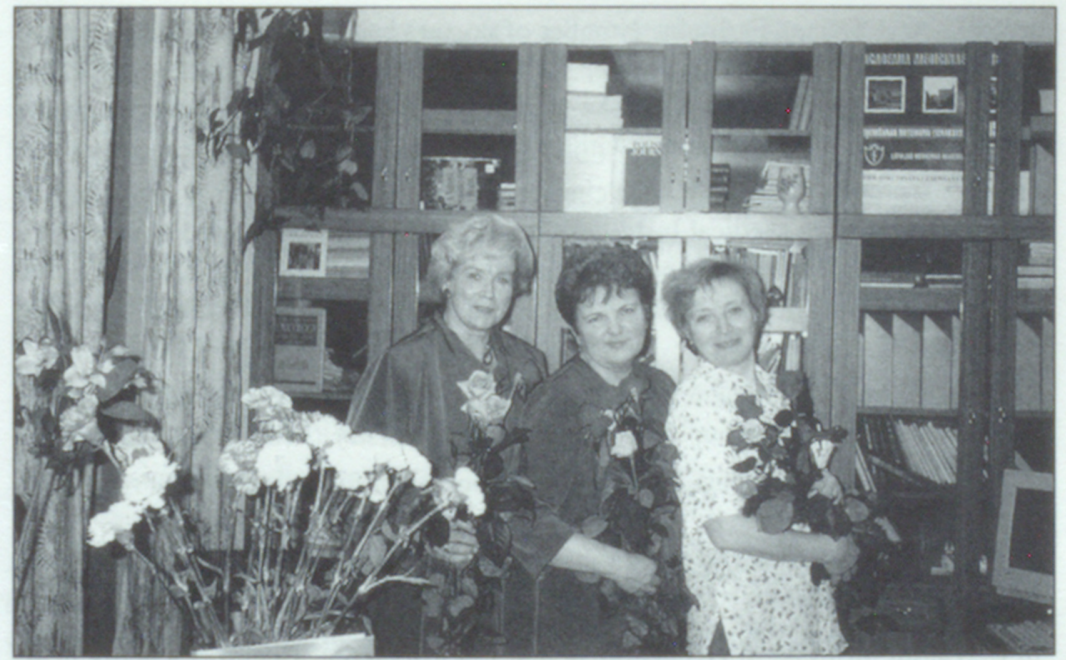

Maija Eglīte (from left), Dagmara Sprūdža, head of the Laboratory, and Mārīte Ārija Baķe, senior scientist, celebrating 30 years since establishment of the Laboratory of Hygiene and Occupational Diseases. 1996

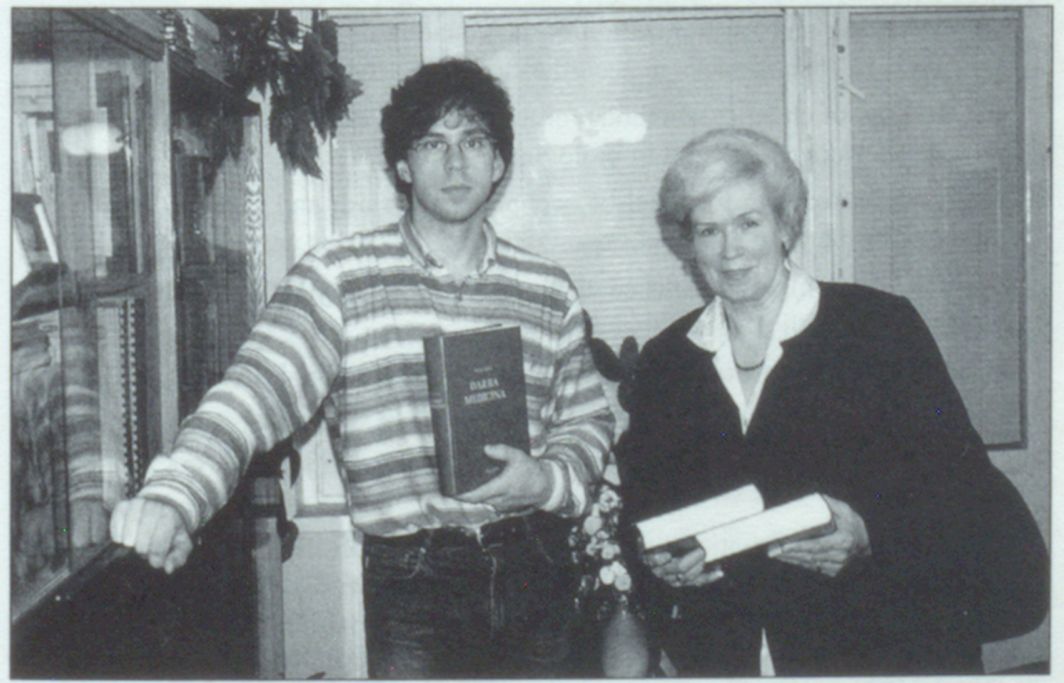

The monography "Occupational Medicine" is finished! Author prof. Maija Eglīte and technical editor Ivars Vanadziṇš. October, 2000 
department is Tatjana Farbtuha. Number of doctors has worked in this department like Êriks Blumbergs, Maija Eglīte, Tatjana Farbtuha, Ingrīda Frickausa, Janīna Hincenberga, Svetlana Karpačevska, Grigorijs Orlikovs, Gunta Rubina, Biruta Pastare, Elīzabete Priedīte and Ksenija Smirnova.

In 1992 Institute of Labour Medicine was established in Medical Academy of Latvia (former Riga Medical Institute). This Institute was reorganized and renamed as Institute of Occupational and Environmental Health at 1996. Prof. Maija Eglīte has headed it since its establishment. After reorganization Institute had following structure:

- Laboratory of Hygiene and Occupational diseases (head Dagmāra Sprūdža) also including group of environmental chemistry (head Marīte Baķe);

- Department of Occupational and environmental medicine (head Prof. Maija Eglīte);

- Center of Occupational and Radiological Medicine of Pauls Stradin's Clinical Hospital.

In Latvia the Institute of Occupational and Environmental Health is leading institution-providing education for all kind of occupational health professionals at different levels. Besides Institute of Occupational and Environmental Health is a leading authority of research in occupational health and safety in Latvia. The Institutes main tasks besides the training are:

1) evaluation and harmonization of TLV standards of different chemical and biological substances in accordance with European standards;

2) workout of chemical methods for the detection of harmful substances in the air of work places and in biological samples;

3) research work in the field of occupational health and safety (done in collaboration with different organizations, enterprises and institutions);

4) providing highly qualified diagnostic and therapeutic expertise for the patients with occupational diseases;

5) creating and updating of data base about occupational diseases;

6) providing expert help to general health services with proper and modern methods for early diagnosis, treatment and rehabilitation of work related diseases.

7) providing information on different aspects of occupational health and safety. It has also started to build and maintain Web pages of Latvian OHS (http://www.parks.Iv/home/ioeh/visitthe.htm) within the recently introduced Baltic Sea Network on Occupational Health and Safety (http://www.balticseaosh.net).

Institutes main research activities continues activities already started by the Department of Hygiene and Occupational diseases: 
1) Occupational health problems of workers working with asbestos in Latvia $[18,22]$;

2) Monitoring of the workers for prevention of occupational diseases in chemical - pharmaceutical enterprises [20,23];

3) Problems connected with chronic lead poisoning in Latvia [15, 20];

4) Research on environmental and occupational allergic diseases [2, 14];

5) Research on occupational lung diseases (i.e. pneumoconiosis, chronic bronchitis etc.) [2, 22];

6) Estimation of health status and follow-up of the Chernobyl's Nuclear Power Station Accident liquidators in Latvia [16, 24];

7) Occupational diseases in the industry of building materials (occupational dermatosis, pneumoconiosis, asbestosis etc.) [2].

These are main research activities of the Institute during 1986-2000. Main focus has been on prevention of workers health. During last 15 years more than 20000 workers have been investigated using different clinical, epidemiological, immunological, physiological, biochemical and hygienic methods. Data analysis has resulted in many scientific articles and $\mathrm{Dr}$. habil. med, thesis for M. Eglite and I. Kvjatkovskaja and Dr. Med. thesis for L. Samsutdinova, T. Farbtuha, L. Ka]inina and etc. [11, 14].

Institute of Occupational and Environmental Health has extensive collaboration with research institutes from Russia, Ukraine, Denmark, Norway, Finland, Sweden, Belgium, Canada, Estonia, Lithuania, France, Hungary, Italy, Japan, Poland and U.S.A.

Development of occupational health in Latvia has also been influenced by participation in international projects. The most important project for the development of Institute of Occupational and Environmental Health has been EC Tempus Phare project "Institute of Occupational and Environmental Health" (1996-1999).

Institute of Occupational and Environmental Health plays an important role in system of occupational health as it providing education and training of students and postgraduates, providing scientific background for work place improvements and diagnostic, clinical and rehabilitation expertise for occupational diseases.

After the regaining of independence Latvia faced serious economical difficulties that also caused problems to occupational health services (OHS) as they are very closely related to overall problems of economics. Most important task for all countries in transition is reorganization of OHS originally created for system of central planning (former Soviet Union) to market driven economy whit it's dynamic development. It is also essential to follow the international directives concerning organization of $\mathrm{OHS}$ on a way to becoming a modern European country. Latvia has already ratified several ILO Conventions and EC Directive 89/391/EEC on the introduction of measures to encourage improvements in the safety and health of workers at work. 
During Soviet times, special departments in the State Sanitary Epidemiological Stations dealt with problems of occupational hygiene. Occupational hygienists' main functions were regular inspections and a measurement of hazardous factors in workplaces, leading to control. At that time there were around one hundred occupational hygienists working in Latvia.

The social and economic transition has introduced new trends in the development of Occupational Health. Now, under a Labour Code (in force since 1972 with changes adopted in 1992,1993 and 1996) and Law on Labour Protection (1993) Latvian employers are responsible for the fulfilment of hygienic and medical measures for the benefit of workers' health. At the moment development of new and proper system of Occupational Health and Safety with set of new legislation coming into power from 2002. Most important among them will be the new "Law on Labour Protection" (transferring requirements of EC Directive 89/391/EEC) and "Law on compulsory insurance against occupational diseases and accidents" (1995).

After the regaining of independence in Latvia, the State Sanitary Epidemiological Stations were closed or restructured to Environmental Health Centres. Most occupational hygienists had changed their occupation due to the economic situation; now, 30 occupational hygienists are still active in the field, many employed by the State Labour Inspection that was re-established in 1993. The main tasks of SLI are - inspection of work conditions at workplaces; supervision of work relations between employer and employee; co-ordination of a tripartite system; issuing of licenses to "legal persons" providing training in occupation safety; issuing of licenses for the introduction and use of the dangerous equipment; investigation of work accidents and occupational diseases; registration of dangerous equipment; participation in the creation of regulatory documents in occupational health; consultations for employers and employees about questions related with occupational health and safety; training of labour inspectors.

During the Soviet era, there was ubiquitous $\mathrm{OH}$ standards for the work environment, established in Moscow. The main difference from Western standards was that only human health and not the technical and practical aspects were considered during the elaboration of the standards. So, we had very strict and safe standards that nobody was able to fulfil [19].

The Technical Committee on the Working Environment now adopts standards, at the National Centre for Standardization and Metrology. Standards are developed taking into account the requirements of the European Commission, standards of other Western countries and standards of former Soviet Union. Right now there are around 50 standards for chemical substances already adopted, taking into account $\mathrm{EC}$ requirements. Another 10 standards have been elaborated taking into account standards of other countries. Standards for noise and vibration are currently under development and will be adopted soon. 
Since the breakdown of the Soviet Union, control of working conditions in almost all industries is unsystematic and is mainly based on the services provided by various laboratories, either from the Environmental Health Centres or factories. Besides that, some independent/research laboratories have been starting to offer their services. That has been possible because of the recently introduced obligatory certification of laboratories performing hygienic measurements.

Medical surveillance or health examinations ought to be seen as a part of occupational health service activities and not as a separate activity. In Latvia health examinations have been ensured by regulations about "Compulsory health status control and teaching of first aid" issued by Cabinet of Ministers in 1997 and "Order of health examinations" (issued by Ministry of Welfare in 1998) as well as by list of officially accepted occupational diseases (issued by Cabinet of Ministers in 1998). Changes in system of occupational health services in Latvia have also caused shortage of well-educated specialists in occupational health. Training and certification of occupational health specialists is one of the functions of the Latvian Association of Occupational diseases physicians that was founded in 1994 and Association of Occupational health physicians that was founded in 1996. On $1^{\text {st }}$ of January 2001 there were 301 certified occupational diseases physicians and 33 certified occupational health physicians (hygienists).

Most common occupational diseases in Latvia are diseases of respiratory organs, muscles and skeletal disorders, disorders of peripheral nervous system, vibration disease as well as allergic diseases and different occupational poisonings [2]. During period from 1981 till 2000 from 110 to 495 new cases of occupational diseases were revealed. In 1981 there were 5.1 occupational diseases on 100000 workers, in $1989-10.7$, in $1994-23.5$, in $1999-35.5$ and in $2000-47.7$. These are still significantly lower numbers than in average European countries where $300-500$ occupational diseases on 100000 workers are registered. In Russia these numbers are even lower than in Latvia - for example in 1999 there were 17.2 cases on 100000 workers. Increased numbers of firstly registered occupational diseases during last years can be explained with improvements in legal requirements as well as with rising number of qualified occupational diseases physicians.

Judging by statistics on occupational diseases there are still many diseases that are not diagnosed and registered. This can be explained by badly organized occupational health services in majority of small and medium size companies as well as with people trying to hide their diseases in order not to loose their jobs. Knowledge on occupational health is also still insufficient among many doctors.

\section{References}

1. Eglīte M., Aleksejevs J., Izrailietis L., Nikiforova A. Antibiotiķu rūpnieciskâs toksikologijas jautājumi // Latvijas PSR Zinātnu Akadēmijas Vēstis. - 1972. - 6. 112. -118 . Ipp. 
2. Eglīte M. Darba medicīna. - Rīga, 2000. - 704 lpp.

3. Izrailietis L., Eglīte M., Hincenberga J., Hlebnova L. Ķīmisko vielu izraisītās profesionālās slimības. - Rīga: Zinātne, 1976. - 97 Ipp.

4. Izrailietis L., Trahtenbergs I. Darba higiēna. - Rīga: Zvaigzne, 1978. - 205 lpp.

5. Izrailietis L., Eglīte M. Arodslimības. - Rīga: Zvaigzne, 1981. - 210 lpp.

6. Артамонова В. Г., Шаталов Н. Н. Профессиональные болезни. - Москва: Медицина, $1996^{3}$. -322 с.

7. Измеров Н. Ф., Монаенкова А. М., Попова Т. Б. Общие теоретические вопросы профессиональной патологии // Профессиональные заболевания / Под ред. Н. Ф. Измерова. - Москва : Медицина, 1996². - Том 1. - С. 14-52.

8. Израйлет Л. И. (редактор). Гигиена труда и промышленная токсикология: Сборник научных статей. - Рига: Рижский медицинский институт, 1974. $-193 \mathrm{c}$.

9.Израйлет Л. И. Гигиена и профессиональные заболевания // Сборник научных статей. - Рига: Рижский медищинский институт, 1980. - 175 с.

10. Блюгер А. Ф., Эглите М. Э. (редакторы). Промышленная аллергология и иммунология: Сборник научных статей. - Рига: Рижский медицинский институт, 1981. - 177 с.

11. Эәлите М. Э. (редактор). Актуальные вопросы гигиены труда и профпатологии в промышленности и сельском хозяйстве: Сборник научных статей. Рига: Рижский медицинский институт, 1984. - 334 с.

12. Эәлите М. Э. (редактор). Гигиена труда и профессиональная патология: Сборник научных статей. - Рига: Рижский медицинский институт, 1987. - 298 с.

13. Эәлите М. Э. Аллергические заболевания у птицеводов. - Рига: Зинатне, 1990. $-170 \mathrm{c}$.

14. Трахтенберг И. М., Тимофеевская Л. А., Квятковская И. Я. Методы изучения хронического действия химических и биологических загрязнителей. - Рига: Зинатне, 1987. $-170 \mathrm{c}$.

15. Bake M. A. Biological Monitoring of metals as indicators of pollution // Proc. Latvian Acad. Sci. - 1998. - Section B, vol. 52, supplement. - Pp. 24-29.

16. Curbakova E., Farbtuha T., Zvagule T., Eglite M., Jekabsone I., Eglite A. The health status of Chemobyl nuclear power plant accident liquidators // Proc. Latvain Acad. Sci. - 1998. - Section B, vol. 52, supplement. - Pp. 187-191.

17. Edling $C$., Waldron $H$. The medical role in occupational health // Occupational Health Practice / Editors H. A. Waldron, C. Edling. - Oxford: ButterworthHeinemann Ltd, $1997^{4}$. - Pp. 1-17.

18. Eglite M., Jekabsone I., Jekabsone J., Bake M. A., Podniece Z., Sprudza D. Asbestos in Latvia // Proc. of International Asbestos Symposium. - Helsinki: Finnish Institute of Occupational Health, 1998. - Pp. 50-54.

19. Eglite M., Jekabsone I., Jekabsone J., Vanadzins I. Ethical aspects of occupational 
health in countries in transition // People and work: Research report Nr. 21. Helsinki: Finnish Institute of Occupational Health, 1998. - Pp. 94-98.

20. Eglīte M., Veide A., Bake M. A., Rusakova N., Makene V. Health consequences of occupational exposure to lead in Latvia // Proc. Latvian Acad. Sci. - 1998. Section B, vol. 52, supplement. - Pp. 205-207.

21. Global strategy on occupational health for all: Recommendations of the second meeting of the WHO Collaborating Centres in Occupational Health 11-14 October 1994, Beijing, China. - Geneva; Helsinki: Printed in Mikor, 1995. - 68 p.

22. Jekabsone J., Podniece Z. The influence of asbestos fibres on health of building material production workers // Proc. Latvian Acad. Sci. - 1998. - Section B, vol. 52, supplement. - Pp. 203-205.

23. Sitova $O$., Socnnevs A., Eglite M., Baķe M. A. Cellular immunity changes in healthy workers of pharmaceutical factory // Proc. Latvian Acad. Sci. -1998. - Section B, vol. 52, supplement. - Pp. 214-217.

24. Viel J. F., Curbakova E., Dzerve B., Eglite M., Zvagule T., Claude V. Risk factors for long term mental and psychosomatic distress in Latvian Chernobyl liquidators // Environment. Health Perspectives. - 1997. - Vol. 105, suppl. 6. - Pp. 1539-1544.

Dr. habil. med., Prof. Maija Eglīte

Dr. Ivars Vanadziňš

Institute of Occupational and Environmental Health

Riga Stradiņš University

Dzirciema 16, Riga, LV 1007

Latvia 
